\title{
RESEARCH ON TAX ADMINISTRATION REFORMS IN THE RUSSIAN PRACTICE"
}

\author{
Mariya A. EVNEVICH ${ }^{\mathrm{a},}$, Dinara V. IVANOVA $^{\mathrm{b}}$
}

\author{
a Saint-Petersburg State University (SPbSU), \\ St. Petersburg, Russian Federation \\ m.evnevich@spbu.ru \\ https://orcid.org/0000-0001-5137-8060 \\ b Saint-Petersburg State University (SPbSU), \\ St. Petersburg, Russian Federation \\ d.v.ivanova@spbu.ru \\ https://orcid.org/0000-0002-7250-9186 \\ - Corresponding author
}

\section{Article history:}

Article No. 69/2020

Received

11 February 2020

Received in revised form

25 February 2020

Accepted 10 March 2020

Available online

29 June 2020

JEL classification: E62, H21, H25, H61, H71

Keywords:

taxation, tax

administration, tax

monitoring

\section{Abstract}

Subject. The article deals with the scope of application of digital technologies to tax monitoring and administration. Digitalization plays an important part in activities performed by the Federal Tax Service and helps reduce the administrative workload on both taxpayers and tax authority. The use of digital communication channels saves our time, because it allows to submit tax returns and send letters online. Furthermore, it enhances the efficiency of inoffice audits and helps identify eventual tax violations.

Objectives. We review a set of digital services and technologies used by the Federal Tax Service, their effectiveness, and present our findings on taxpayers' attitude to ongoing digital reforms.

Methods. The validity and argumentation are based on official statistics of the Federal Tax Service concerning the dynamics of tax revenues and inspections, quantitative research through questionnaires and analysis of the findings.

Results. We examine a range of digital services and technologies, including the Automated Control System - Value Added Tax, a new type of cash registers - Automated Information System Marking, Federal Government Information System - Unified State Register of Civil Registry Office, and personal accounts of taxpayers. Moreover, the article presents results of a survey among owners and top managers of companies, identifying their opinion on the coming taxation reforms.

Conclusions and Relevance. Digitalization helped the Federal Tax Service significantly increase the efficiency of tax audits, while reducing the frequency of tax audits and the number of fly-by-night companies and the likelihood of using informal tax administration schemes. However, authorities should find a balance between the enhancement of the taxation system and their relationship with businesses.

(c) Publishing house FINANCE and CREDIT, 2020

Please cite this article as: Evnevich M.A., Ivanova D.V. Research on Tax Administration Reforms in the Russian Practice. Digest Finance, 2020, vol. 25, iss. 2, pp. 157-169. https://doi.org/10.24891/df.25.2.157 
The government authorities consider digitalization to be an attractive tool for many reasons. For example, it enables the tax authorities to receive an additional outlook of the economic status and state of affairs of taxpayers, thus allowing them to close the 'tax gap'. Digitalization also reduces the administrative workload upon both fiscal authorities and taxpayers per se. Besides, in many countries we can see evident achievements in implementing their taxation system digitalization programs [1].

For example, Australia has been implementing the Digital by Default Strategy since 2013, assuming that it is much more convenient for their taxpayers to contact government authorities through digital communication channels, being highly widespread due to the Strategy realization. In particular, the Australian Taxation Office (ATO) efficiently promotes online discussions on tax issues with their taxpayers via e-mail, while the major amount of the public services are provided through the Central Portal "MyGov". This Portal applies the two-factor authentication; it allows the tax agents to act on behalf of the clients and supports voice recognition technology as a means of identifying the taxpayers [2].

Another example is the Project to be realized in the United Kingdom, with its dominating service sector (80\%) in the domestic economy and the emphasis upon the financial sector. The UK Government is one of the most digitally advanced authorities, being the head of the D5 Group (Great Britain, Israel, New Zealand, South Korea and Estonia). The United Kingdom has introduced the electronic filing of VAT reports, personal and business tax returns, it allowed to achieve a share of $99 \%, 86 \%$ and $98 \%$ in online tax returns, respectively. In addition, the UK Government has launched an investment program aimed at complete transformation of the annual tax returns by 2020. Currently, the UK taxation system applies the schedule of the mandatory reporting on a quarterly basis; reports are pre-filled by taxpayers and then aggregated in the HMRC database (Her Majesty's Revenue and Customs database). Thus, the HMRC is authorized to track all the inconsistencies related to the payments, along with taxpayers' activities during the whole year.

It's worth noting that the quarterly reporting costs are borne by taxpayers. In addition, the digitalization of the taxation system is rather aggressive and has a short implementing period, which also causes an increase in taxpayers' expenses, especially for those ones who work with small businesses.

Despite problems of transition from the centralized management to the market economy, Russia has ultimately been recognized as one of the most stable economies of the world. Russia has a much shorter history of digitalization than many other countries, although, in some aspects, their milestones are very similar. Within a short time Russia launched a digitalization program for taxation services, being supported by the central authorities, i.e. the Federal Tax Service (FTS), which has a clear concept to put digital services at the center of its activities. Moreover, the intense pilot implementation of such innovations in Russian regions had considerable importance.

\footnotetext{
"For the source article, please refer to: Евневич М.А., Иванова Д.В. Исследование реформ налогового управления в российской практике // Финансы и кредит. 2020. Т. 26. № 4. С. 898-915.

URL: https://doi.org/10.24891/fc.26.4.898
} 
Despite the fact that Russia has been lagging 5-8 years behind economic digitalization leaders $^{1}$, on the contrary, the country holds one of the leading positions in tax administration. The FTS acts not only as a partner in cooperation with foreign tax services, but it is a developer of various software solutions aimed at the digital transformation of tax administrations as well.

In general, the Federal Tax Service follows two directions:

- establishing confident relations between businesses and tax authorities;

- applying more transparent and understandable tax administration methods interacting with bona fide taxpayers instead of fiscal methods.

In the mean time, improving the overall quality of government control, reforms are intended to decrease administrative burden upon business in terms of control and supervision [3].

As for milestones of Russia's progress of tax administration, we should mention the introduction of a risk-based approach. It was put in use last decade [4, 5]. Nowadays, the approach underlies all the steps of tax audits, i.e. planning, preparation and performance [6]. Basically, the risk assessment concept is based on twelve tax breach criteria. For example, taxpayers with a low tax burden represent risk exposure as they report their losses on a regular basis, claim for excessive tax deductions and underpay their employees if compared with the respective average in the analyzable constituent entities of the Russian Federation. Thus, all taxpayers are classified by degree of a probable taxation threat and distributed by respective related risk levels. This helps identify the most bona fide counterparts. According to the statistics of the Federal Tax Service, the risk-based approach has reduced the duration of in-office audits checking tax returns on excise taxes on ethyl alcohol, alcoholic and excisable alcohol-containing products, making them last two months instead of three ${ }^{2}$. If the tax risk is low or medium, in-office audits can take less than three months ${ }^{3}$.

Digital services and technologies are key means the Federal Tax Service uses to implement the tasks:

\section{Platform for VAT / VAT-2 / VAT-3 Automated Control System (VAT / VAT 2 / VAT 3 ASC)}

The VAT ASC was launched in the Russian Federation in 2013 in order to increase the efficiency of in-office audits. It is designed to determine entities with the highest risk of tax violations [7].

\footnotetext{
${ }^{1}$ Makurova T. [Digitalization of tax administration]. Metod = Method, 2018, no. 2. URL: http://gosmetod.ru/article/356082/ (In Russ.)

${ }^{2}$ On the Reduction of the Office Audit Time: Letter of the Federal Tax Service of the Russian Federation of July 27, 2018 № MMB-20-15/85@. URL: http://www.consultant.ru/document/cons_doc_LAW_304540/ (In Russ.)

${ }^{3}$ As per Paragraph 2, Article 88 of the Tax Code of the Russian Federation.
} 
Having introduced the VAT-2 ASC, tax authorities managed to optimize in-office audits by checking tax returns immediately upon receipt with electronic purchase and sales ledgers to be stored in the ASC [8]. High profile companies filed 10 times as fewer VAT refund applications fir the recent year during which the VAT-2 ASC was used [9]. The VAT-2 ASC helps determine if the taxpayer enjoys unreasonable VAT benefits. According to A. Egorichev, the Head of the Department for In-Office Audits of the Federal Tax Service of the Russian Federation, what mainly the VAT-2 ASC monitors are tax returns revealing undeniable breaches in Control Contract 1.27-1.28, doubtful debts, and discrepancies of accounts. Due to the application of the VAT-2 ASC, in H1 2017 revenue increased by $33 \%$ year-on-year and amounted to RUB 5.2 trillion.

The VAT-3 ASC serves not only for monitoring VAT, but also comparing it with banking payments. VAT returns have been compared with account statements since October 1, 2017 in order to identify unpaid transactions. According to Tat'yana Il'inova, the Head of the Audit Department with Gradient-Alpha Audit and Consulting Group, the high banking control risk is applicable to those companies whose accounts are either absolutely out of balance or they are minimal and not comparable with the amount of transactions. Besides, if neither payroll transactions were made through the company's account or the payroll amount doesn't correspond to the number of employees, utility fee, rent charges, etc. are not paid either. Thus, fiscal authorities confine their functions onto banks, while the tax authorities are turning into a service institution.

\section{Administration Platform of Cash Register Equipment (CRE)}

The Russian Federation has been implementing a project since July 2016 to adopt a new CRE procedure. The project implies that all taxpayers with old models of cash register equipment should upgrade or replace the CRE with new devices. Once online cash registers were set, taxpayers were allowed to remotely register their CRE, without visiting a tax office in order to file the online cash register. The Law applies to online businesses, when they transact with customers on the Internet. They should connect online cash register, while it automatically records the transaction into a fiscal memory device (FMD) and transfers data to the fiscal data operator (FDO).

Online cash registers transfer online transaction details to tax authorities. Online cash registers automatically transmit the transaction data. This helps reduce the number of onsite inspections and enhances the business monitoring function. According to Mikhail Mishustin, who spoke at the Joint International Workshop of the OECD and IOTA (August, 30-September 1, 2017), consequently, the administrative pressure upon entrepreneurs was alleviated, the business environment was improved, while ordinary consumers were provided with an additional mechanism to protect their rights.

During the 1st and 2nd phases of the Project, 105,000 CRE devices were registered in St. Petersburg alone. Starting from January 1, 2019, companies and individual entrepreneurs subject to the unified tax on imputed income, sole proprietors subject to the patent taxation treatment, sole proprietors subject to the unified tax on imputed income and taxpayers providing services to the population, etc., should switch to use those updated devices. 


\section{Marking Automated Information System (AIS)}

In 2016, the fur product marking project was launched in Russia. During its first year, the turnover of related goods demonstrated an eight-fold increase, while 25 percent of legalized market operators left the market.

The trial drug labeling procedure was launched in February 2017. Moreover, this project was not only to identify taxpayers, but also served for social purposes. The would-be customers could scan a QR-code on the package to learn about a manufacturer and avoid buying a low-quality and counterfeit medicines.

\section{Federal Governmental Database of the Uniform State Register of the Civil Registry Office}

The web portal of the Unified State Register of Civil Registry Office was opened on September 1, 2018. It is subject to Federal Law, On Vital Records, of June 23, 2016 № 219-Ф3. The creation and completion of the Civil Registry is the responsibility of the Federal Tax Office. Using the new system, employees of the Civil Registry Office can register marriages more easily and legally significant actions in the electronic form. Besides, using the system, citizens can obtain certificates and other documents more easily, regardless of their place of residence. In the mean time, departments interact electronically, while fiscal authorities can access the information about both marital status and family ties, referring to the information about birth, death, paternity, etc.

\section{Personal Accounts of Taxpayers}

Personal accounts of taxpayers are provided through online services that allow them to exercise their rights and obligations in accordance with the Tax Code of the Russian Federation. Personal taxpayer accounts for individuals keep users updated about property and transport issues, taxes paid and accrued. They also enable people to pay debts, and address tax authorities without any personal visits to the tax office. Moreover, authorities launched personal taxpayer accounts for sole proprietors and personal taxpayer accounts for legal entities $[10,11]$.

Starting from January 1, 2017, foreign providers of electronic services or sellers of online content to the Russian users must be registered with the Russian tax authorities. For convenience, authorities created personal accounts for foreign entities, allowing foreign entities to apply directly, i.e. filing VAT returns, tracking payments, submitting changes to credentials, etc. [12]. Google, Apple, Samsung, Microsoft, etc. were given access to such personal accounts.

\section{Tax Monitoring}

In the Russian Federation, the Federal Tax Service has been responsible for tax monitoring since January 1, 2016. Tax monitoring is an attempt to digitize the interaction between the taxpayer and tax authorities so as to switch from traditional tax control, such as in-site inspections and in-office audits, to the immediate online verification of data. In 
general, tax monitoring serves control whether the tax base is correctly assessed, as well as the calculation of tax amounts, compliance with tax payment schedules. As part of tax monitoring, the company lets tax authorities see fiscal and accounting data [13].

While adopting the tax monitoring procedure, companies get an advantage of requesting tax authorities to perform and inform the result of current transactions. Consequently, there may be fewer controversies. This will also facilitate tax monitoring as fewer documents will be required and taxpayers are relieved from additional charges for taxes, penalties and fines because the taxpayer will have a preliminary response of tax authorities concerning the deal in question [14]. Meanwhile, the tax monitoring procedure is available only for some entities, which are the biggest market actors ${ }^{4}$. According to Daniil V. Egorov, the Deputy Head of the Federal Tax Service of the Russian Federation, it helps reduce the deadline for closing the tax period from 4.6 years as per the traditional scheme to 1.9 years in case of tax monitoring. In 2017, major companies in various industrial sectors, such as Rosneft, Novatek, Unilever Rus, InterRAO, Megafon and MTS, Ernst\&Young, etc. introduced the tax monitoring procedure. In 2018, it was integrated in Aeroflot, Google, NTV Television Company, as well as subsidiaries of industrial corporations, such as Lukoil and Norilsk Nickel.

At the moment, the Federal Tax Service (FTS) finishes implementing its projects. According to statistics, the decisions prove to be effective. So, there were six times as less shell companies from 2011 to 2017 (from 1.8 million in 2011 up to 300 thousand in 2017). Despite the unstable economic situation, tax revenues to the consolidated budget increased by more than 50 percent in nominal terms and by almost 20 percent in real terms from 2013 to 2017 (Fig. 1). It's important to note that 60 percent (RUB 1.7 billion) of revenue do not proceed the oil and gas sectors, while the effect of tax administration is estimated to amount RUB 400 billion. In addition, tax revenues grew by 21.5 percent from January to August 2018 year-on-year (Fig. 2).

What is more, according to the Federal Tax Service, as digital technologies for online monitoring of taxpayers spread, there have been conducted fewer in-site inspections, dropping by 40 percent in 2017 year-on-year. Moreover, every audit session continuously demonstrated higher efficiency from 2013 through Q3 2018. This became possible due to additional payments accrued per audit session (Fig. 3). Thus, on-site inspections reduced on average by 16.4 percent during the period from 2013 to 2017, while the efficiency grew by 22.7 percent on average.

Inspections have become 2.3 times as effective for the recent five years as they were. As of October 1, 2018, every thousand of inspections generated RUB 22 billion in additionally accrued payments. 10.9 thousand inspections were carried out. This factor is twice as less as for 2017 entirely. Thus, due to the risk-based approach, on-site inspections cover less than one percent of taxpayers, while, for instance, in the European Union, domestic tax authorities audit 2-3 percent of entities on average, whose performance indicators are more or less the same [15].

${ }^{4}$ As per Paragraph 3, Article 105.26 of the Tax Code of the Russian Federation. 
One way or another, it is still doubtful whether the tasks meet the factual results of the fiscal reform. For example, even monitoring taxpayers online, tax authorities cannot assess the risk completely. Consequently, they can choose a fraudulent counterpart accusing it with fraud or fraudulent attempts (for example, accusations of illegal activities, claiming to withhold VAT). Hence, the business risk grows, though the fact never correlated with the scope of reforms. Moreover, taxpayers incur much higher financial costs to install cash register equipment (CRE) than the amount reported in VAT returns. The lack of 100-percent Internet coverage throughout the Russian Federation also causes additional problems for businesses. Nevertheless, we cannot say the reform has adverse effects at least because proceeds and results of inspection sessions statistically reveal the positive dynamics.

Seeing the facts, we come to a logic question. What do taxpayers think about the taxation reforms? [16] To answer it, we surveyed representatives (i.e. top managers and the owners) of 115 companies from various sectors of the Russian economy [17]. The largest share of respondents (23.5 percent) works in wholesale and retail. Fig. 4 classifies respondents by industrial sector.

The respondents were asked about various aspects of the ongoing reform of the Federal Tax Service:

- tax burden;

- administration workload;

- VAT;

- CRE;

- tax discipline and attitude of the Federal Tax Service to taxpayers.

In general, more than 70 percent of respondents believe that the reform of the Federal Tax Service has curbed shadow taxation schemes over the recent three years. This is mainly due to the adoption of electronic VAT invoices, CRE devices, as well as analyzing the banking documents by the tax authorities (Fig. 5).

According to about 70 percent of respondents, the tax burden on their businesses has increased for the recent three years, while 50 percent of them do not mention changes in tax administration as possible causes (Fig. 6). Moreover, if the tax burden grows, 90 percent of respondents are ready to assimilate the changes and remain in the market. Moreover, according to 60 percent of respondents, the digitalization of the taxation system has never resulted in a lower administrative workload. We should note that it is precisely the decreasing administrative workload that the reform of the control-andsupervision system in the Russian Federation is intended for. Importantly, if the Federal Tax Service continues to change the tax and administrative workload and keep the same rate, over 50 percent of respondents predict companies will hide in the informal sector. 
Only 48 percent of respondents comment on the situation as the VAT procedure is being digitized, while the rest of the respondents either say nothing or work through the simplified system of taxation [SST]).

Thus, the remaining 52 percent of respondents from 40 percent of companies are encouraged by the Federal Tax Service to go totally transparent. Meanwhile, according to 21.6 percent of respondents, the introduction of ACS VAT-2 just induced the spread of the informal sector. As a result, 14.9 percent of respondents report that relations between suppliers and contractors were affected, while 30.8 percent of them were either slightly or not affected at all.

Only 35 percent of respondents has been impacted due to the replacement of online cash registers in the course of the reform, while 50 percent of them incurred significant costs, and 22 percent improved the discipline of their employees.

Although 67.8 percent of companies surveyed call the tax system digitalization is a driver of the tax discipline, while only 12.2 percent of respondents believe that the Federal Tax Service strives to further dialogue, interaction with businesses and a reduction of of fines applicable to taxpayers. Despite the doubts, the fact signifies the reform reached its goals.

The digitalization can possibly reduce costs of the taxation system, both for the government handling the tax administration, and for taxpayers operating in this environment. There are appropriate approaches to consider, and hidden rocks to be detected. For example, further tests, pilot surveys and phased implementation will simplify and streamline the transition to digital administration methods. On the other hand, the introduction of new mandatory systems will make taxpayers bear the costs, hitting the private sector.

The Russian Federation proves the bilateral nature of reforms. Thus, the digitalization helped the Federal Tax Service significantly enhance tax audits and make them less frequent. It also almost exterminated shell companies and options for shadow administration schemes in taxation. However, taxpayers did not feel the undeniable effect of the reform. The changes induce significant costs. Businesses do report on a significant progress and higher business indicators. One way or another, the digitalization is an inevitable process of our time, changing the technological landscape. The only question is whether the authorities can find a balance enhancing the taxation system and establishing their relationship with businesses. 
Figure 1

The dynamics of tax revenue to the consolidated budget of the Russian Federation, 2013-2017

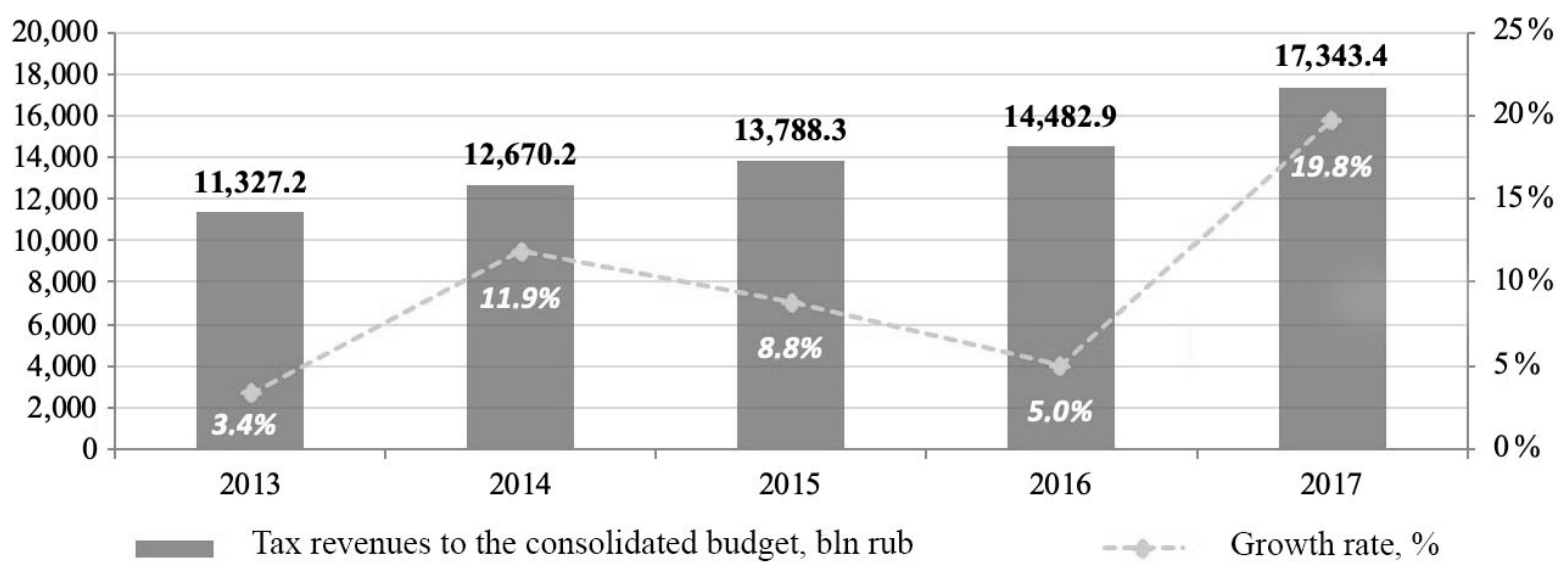

Source: Authoring based on the Federal Tax Service data.

URL: www.analytic.nalog.ru/portal/analytical_information.ru-RU.htm (In Russ.)

Figure 2

The dynamics of tax revenue to the consolidated budget of the Russian Federation, billion RUB, January through August 2017-2018

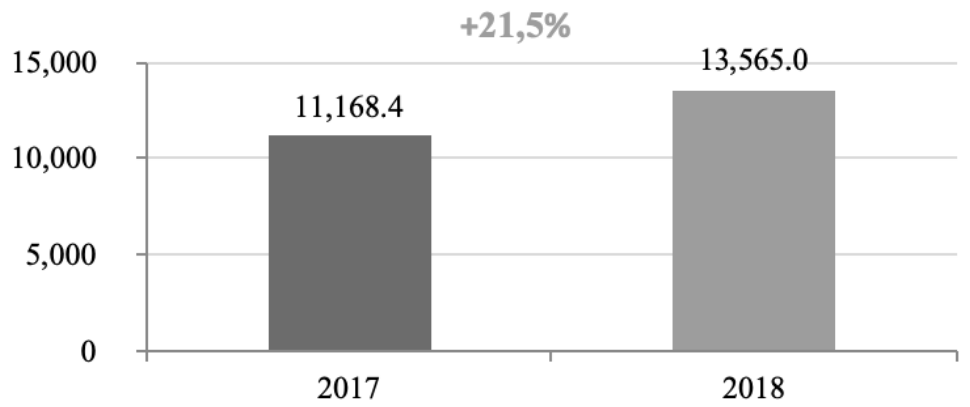

Source: Authoring based on the Federal Tax Service data.

URL: analytic.nalog.ru/portal/analytical_information.ru-RU.htm (In Russ.) 
Figure 3

The dynamics of field tax audits of the Federal Tax Service and their efficiency per one thousand units, 2013 through Q3 2018

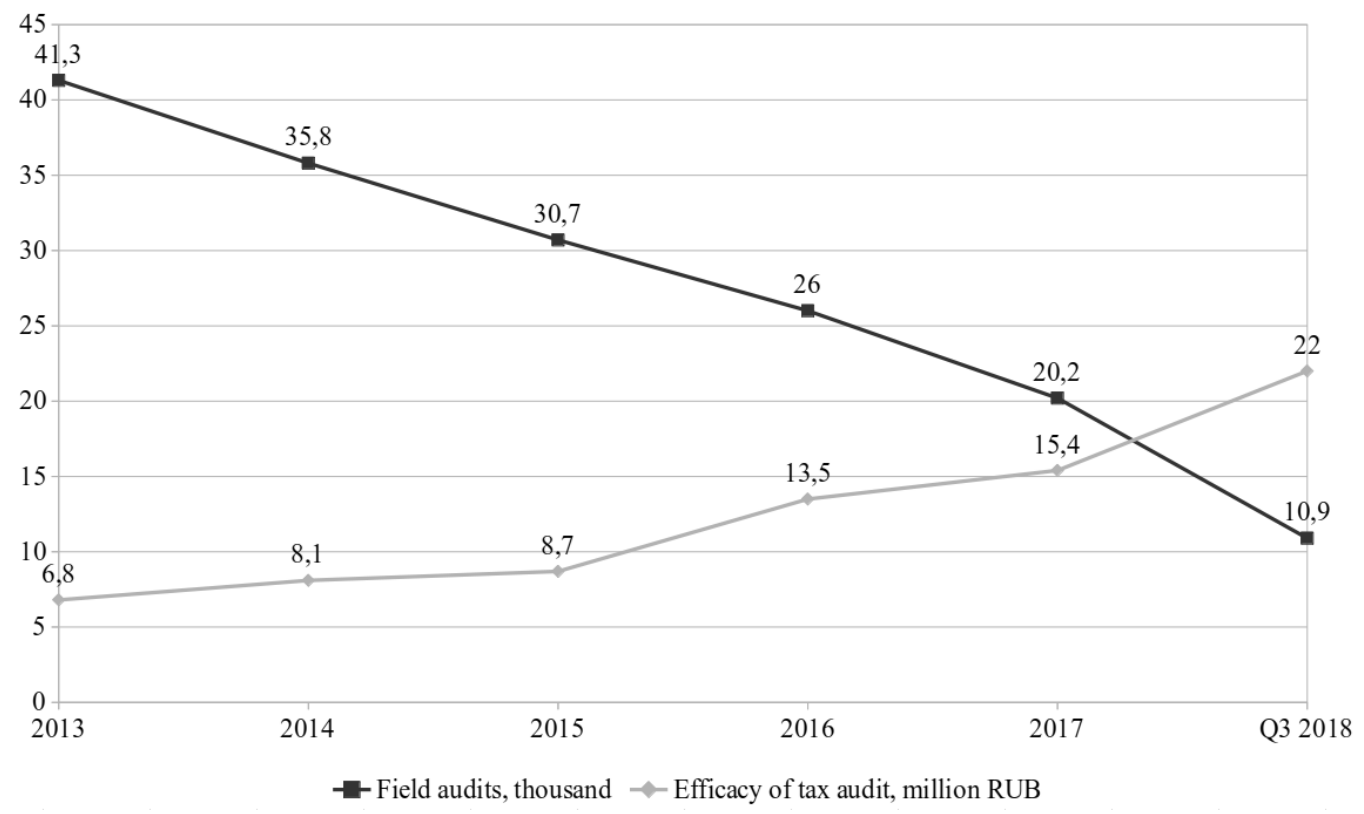

Source: Authoring based on the Federal Tax Service data.

URL: analytic.nalog.ru/portal/analytical_information.ru-RU.htm (In Russ.)

\section{Figure 4}

Respondents broken down by sector

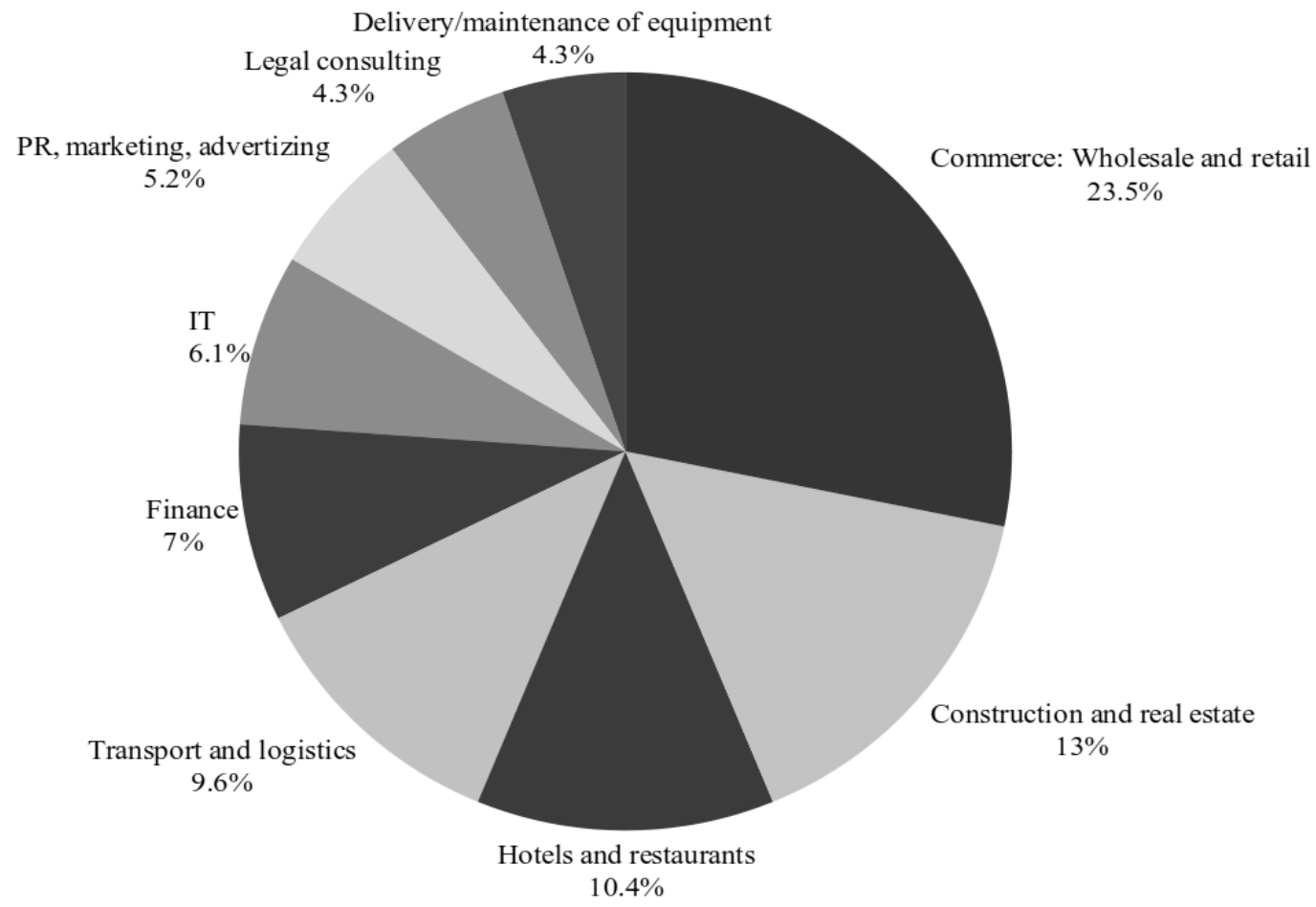

Source: Authoring 
Figure 5

Key causes curbing the use of tax shopping, according to respondents, percentage of responses

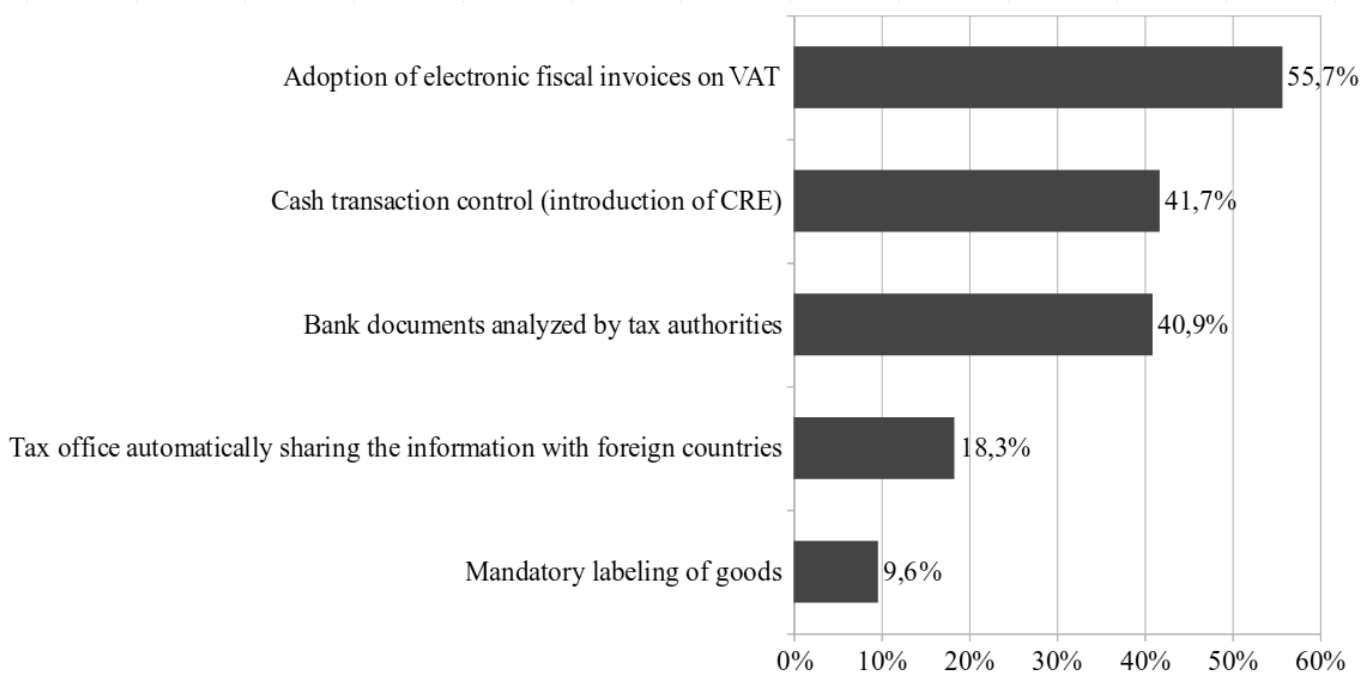

Source: Authoring

\section{Figure 6}

Answers as to whether the tax burden of respondents' business has increased for the recent three years

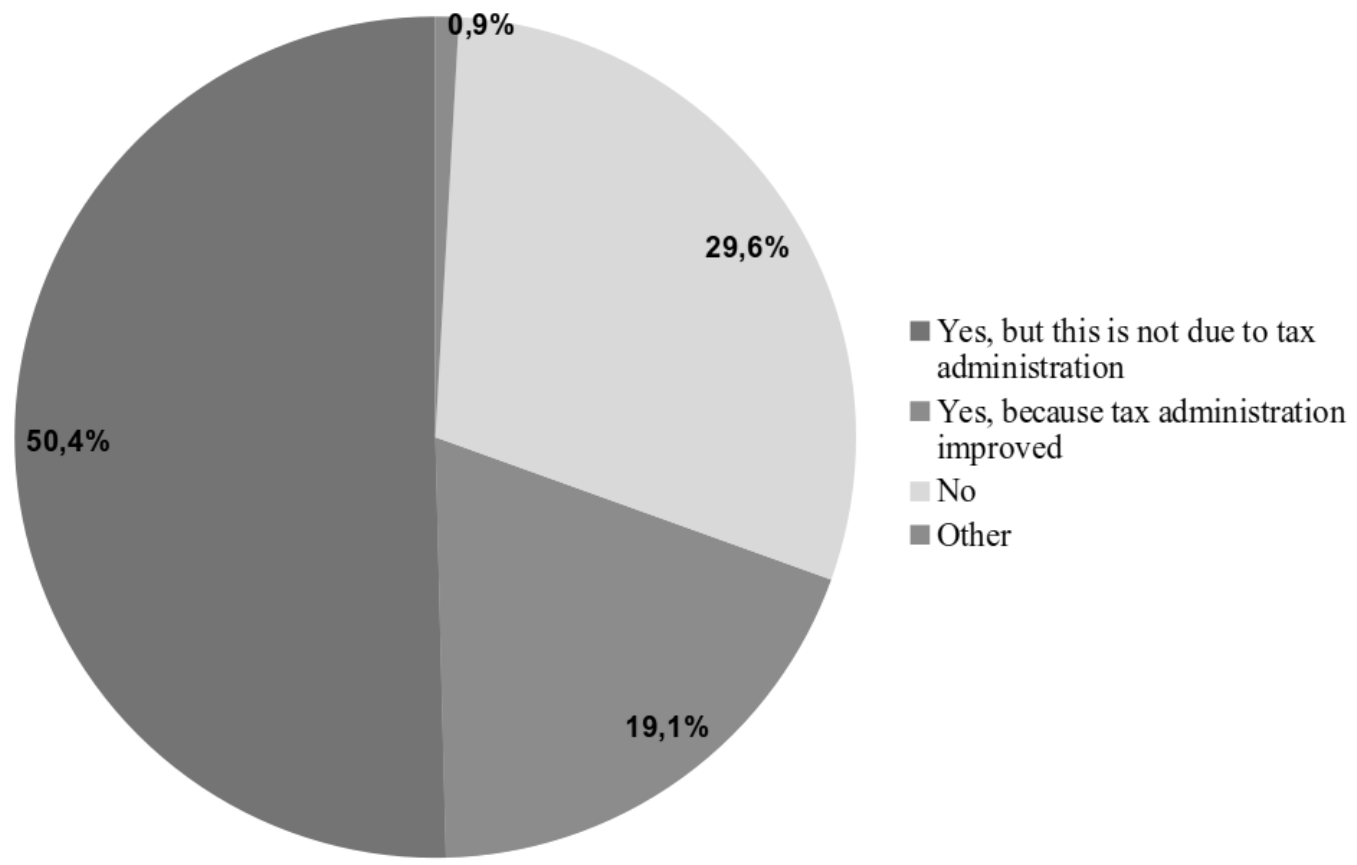

Source: Authoring 


\section{Acknowledgments}

The survey herein was supported by Irina Yu. POLYAKOVA, Master's Degree Program first-year student, the Saint Petersburg State University.

\section{References}

1. Petukhova N.V. [Tax administration in terms of modernization of tax authorities activity]. Nalogi i finansy = Taxes and Finance, 2016, no. 3, pp. 34-38. (In Russ.)

2. Anisimov A.L. [The efficiency of tax administration in the tax system of the Russian Federation]. Izvestiya Ural'skogo gosudarstvennogo ekonomicheskogo universiteta = Journal of Ural State University of Economics, 2015, no. 1, pp. 24-30. (In Russ.)

3. Solov'ev A.I. [Risk-based approach in the system of government control and supervision in the tax sphere]. Ekonomika. Nalogi. Pravo = Economics, Taxes \& Law, 2017, vol. 10, no. 6, pp. 139-146. URL: https://cyberleninka.ru/article/n/riskorientirovannyy-podhod-v-sisteme-gosudarstvennogo-kontrolya-i-nadzora-vnalogovoy-sfere/viewer (In Russ.)

4. Novoselov K.V. [Risk management prospects in the tax sphere]. Ekonomika. Nalogi. Pravo = Economics, Taxes \& Law, 2017, vol. 10, no. 6, pp. 29-38.

URL: https://cyberleninka.ru/article/n/perspektivy-razvitiya-risk-menedzhmenta-vnalogovoy-sfere/viewer (In Russ.)

5. Smirnova E.E. [Tax control in the digital economy]. Finansy = Finance, 2017, no. 11, pp. 32-34. (In Russ.)

6. Kirova E.A., Morozova N.G., Bezverkhii A.S. [Transformation of the Russian tax system in the context of establishment of the digital economy]. Vestnik Universiteta, 2019, no. 7, pp. 118-124. URL: https://cyberleninka.ru/article/n/transformatsiyanalogovoi-sistemy-rossii-v-usloviyah-stanovleniya-tsifrovoi-ekonomiki/viewer (In Russ.)

7. Novoselov K.V. [Developing the theory and practice of tax control over the tax base of corporate income]. Innovatsionnoe razvitie ekonomiki = Innovative Development of Economy, 2016, no. 3-2, pp. 188-193. (In Russ.)

8. Grunina D.K. [Information digital technology and activity of the tax authorities]. Nalogi i finansy = Taxes and Finance, 2018, no. 1, pp. 24-34. (In Russ.)

9. Roshchupkina V.V. [Problems and prospects of interaction between entrepreneurs and tax authorities of the Russian Federation in the context of digitalization of the tax administration mechanism]. Ekonomika i predprinimatel'stvo = Journal of Economy and Entrepreneurship, 2019, no. 5, pp. 222-225. (In Russ.) 
10.Gul'kova E.L., Karp M.V., Tipalina M.V. [Tax challenges of the digital economy]. Vestnik universiteta, 2019, no. 4, pp. 89-95.

URL: https://cyberleninka.ru/article/n/nalogovye-vyzovy-tsifrovoy-ekonomiki/viewer (In Russ.)

11. Voronov A.A. [Monitoring as an efficient form of tax control]. Finansy: teoriya $i$ praktika $=$ Finance: Theory and Practice, 2016, no. 2, pp. 145-149.

URL: https://cyberleninka.ru/article/n/monitoring-kak-perspektivnaya-formanalogovogo-kontrolya/viewer (In Russ.)

12. Krashennikova M.A. [Tax Monitoring is the Digital Future of Tax Control]. Nalogovaya politika i praktika = Tax Policy and Practice, 2018, no. 3, pp. 40-43. (In Russ.)

13. Kirillova O.S. [Contemporary technologies of tax administration: Addressing the threats or using the opportunities to ensure the economic security]. Ekonomicheskaya bezopasnost' i kachestvo = Economic Security and Quality, 2018, no. 1, pp. 69-75. (In Russ.)

14. Advokatova A.S. [The interrelation of the tax payer behavior and tax control models]. Ekonomika. Nalogi. Pravo = Economics, Taxes \& Law, 2017, no. 5, pp. 148-157. (In Russ.)

15.Amosova N.A., Vasil'ev A.V. [Risk-focused budgeting as a tool of financial risk management]. Sovremennye naukoemkie tekhnologii. Regional'noe prilozhenie = Modern High Technologies. Regional Application, 2011, no. 4. (In Russ.)

16. Vasenev K.P. [Integration of enterprise management system with application of Beyond Budgeting concept]. Kontrolling = Controlling, 2017, no. 1, pp. 12-25. (In Russ.)

17. Mizikovskii I.E. Genezis upravlencheskogo ucheta na otechestvennykh predpriyatiyakh [Genesis of management accounting at domestic enterprises]. Moscow, Ekonomist" Publ., 2006, 199 p.

\section{Conflict-of-interest notification}

We, the authors of this article, bindingly and explicitly declare of the partial and total lack of actual or potential conflict of interest with any other third party whatsoever, which may arise as a result of the publication of this article. This statement relates to the study, data collection and interpretation, writing and preparation of the article, and the decision to submit the manuscript for publication. 